\title{
DEMOCRACIA EM TRANSE
}

Na primeira semana de novembro de 2020 a atenção do mundo todo se voltou para a eleição presidencial estadunidense. Estava em jogo mais do que a simples substituição do presidente da nação mais poderosa do mundo, mesmo que o derrotado tenha sido o polêmico Donald Trump. Polêmico porque desde o início deixou claro que não confiava no sistema eleitoral e, uma vez proclamado o resultado, contestou a lisura do processo e alimentou várias teorias conspiratórias e acusações de fraude nas urnas. O contexto em que a eleição foi realizada, em meio à pandemia do Covid-19 (e é bom lembrar que os Estados Unidos são até agora o país mais castigado pelo vírus), não facilitou as coisas uma vez que a possibilidade de votar pelo correio resultou numa demora de vários dias para que os votos pudessem ser contabilizados. A confiança na democracia não é apenas uma questão ideológica, visto que está fortemente atrelada à capacidade de as instituições democráticas oferecerem soluções práticas e factíveis para lidar com os desafios das sociedades contemporâneas. Em artigo recente, James Forsyth, editor político da revista conservadora The Spectator, afirma que o Covid-19 não está apenas eliminando vidas, mas também destruindo a crença na democracia. Ele argumenta que até agora os governos autoritários do leste asiático têm sido mais eficazes em enfrentar a pandemia do que os governos das grandes democracias ocidentais: "Esta crise lançou luz sobre os problemas antigos do ocidente, em particular sobre a ineficácia da máquina governamental para os propósitos da era moderna" (Forsyth, 2020, p. 27, tradução nossa). Como afirma um representante do establishment britânico entrevistado por Forsyth, "o individualismo liberal não é a filosofia mais adequada para lidar com algo que causa sofrimento a todos nós, precisamente porque somos todos humanos" (Forsyth, 2020, tradução nossa). Com efeito, observa-se que nos mais variados países a pandemia erodiu a democracia e 
o respeito pelos direitos humanos. Levantamento recente evidenciou que

líderes autoritários descobriram que podem impressionar mais facilmente as massas quando controlam o noticiário. Em abril a organização Reporters Without Borders havia identificado 38 países que utilizam o coronavírus como desculpa para cercear os meios de comunicação mais críticos. Agora este número mais que dobrou, tendo alcançado 91 países, de acordo com a Freedom House. Vários governos criminalizaram as "fake news" sobre a pandemia. Com frequência trata-se de um expediente para deslegitimar opiniões que desagradam o partido do governo. (THE PANDEMIC..., 2020, p. 51, tradução nossa)

É oportuno lembrar que Michel Foucault, ao escrever sobre o panóptico em Vigiar e Punir, descreve detalhadamente as medidas de emergência aplicadas no século XVII quando a peste afligia as cidades. Tais medidas adotadas pelas autoridades consistiam em impor o isolamento social:

Em primeiro lugar, procede-se a um rígido esquadrinhamento espacial: fechamento, é claro, da cidade e do território, proibição de sair sob pena de morte, eliminação de todos os animais errantes; divisão da cidade em bairros distintos onde é estabelecido o poder de um intendente. Cada rua é submetida à autoridade de um síndico; ele a vigia; se a abandonasse, seria punido com a morte. No dia marcado, é dada a ordem para que cada um permaneça trancado em casa: proibição de sair sob risco de vida. (Foucault, 1975, p. 197, tradução nossa)

A reflexão sobre a biopolítica e a vigilância das populações está na ordem do dia, pois 
nossos líderes vão utilizar cada oportunidade de consolidar o seu poder, especialmente em tempos de crise. Não é segredo que o coronavírus está sendo explorado para reforçar a infraestrutura de vigilância em massa. [...] A epidemia vai aumentar o controle de cima para baixo e a vigilância; vai refazer a sociedade como um laboratório para as técnicas disciplinares. (D'Eramo, 2020, p. 24, tradução nossa)

Este é o contexto no qual publicamos este novo número da revista Lua Nova, com nove artigos inéditos que, de uma maneira ou de outra, remetem aos tempos atuais. No primeiro deles Marcelo Sevaybricker Moreira entra no recente debate sobre a crise das democracias no século XXI e discute as causas, sintomas e estratégias para superá-la. $\mathrm{O}$ autor analisa um conjunto de escritos publicados nos últimos anos que identificam uma grave crise das democracias contemporâneas: elas estariam em um processo de "desconsolidação democrática" cujo remédio seria uma restauração da democracia liberal. Em vista disso Moreira argumenta que estamos diante de uma crise muito mais profunda do "capitalismo democrático", que por sua vez é consequência da "revolução neoliberal". O argumento é semelhante ao de Luiz Carlos Bresser-Pereira, que no seu artigo com o sugestivo título "A democracia não está morrendo: foi o neoliberalismo que fracassou" alarga a discussão e sustenta que o verdadeiro problema enfrentado pelos países desenvolvidos é o fracasso do neoliberalismo e da teoria econômica neoclássica que o justifica. Em seguida, no artigo "Tolerância política, neutralidade e pluralismo nas democracias liberais", Ricardo Araujo trata da tolerância política nas democracias liberais, analisando algumas críticas que lhe são dirigidas e mostrando que, apesar delas, sua relevância permanece. No quarto artigo, Paulo Henrique Paschoeto Cassimiro e Felipe Freller abordam a relação entre os conceitos de Estado e sociedade civil na teoria política francesa do século XIX 
a partir da discussão sobre a formação da sociedade pós-revolucionária. O debate teórico continua com Luís Falcão que, no artigo "Uma teoria do conflito não maquiaveliano: o caso de James Harrington", mostra que o conflito político é central na argumentação do teórico político inglês.

No sexto artigo, "O modernismo como movimento cultural: uma sociologia política da cultura”, André Botelho abre uma nova frente de pesquisa sobre o modernismo brasileiro a partir da análise da obra e atuação de um de seus principais líderes, Mário de Andrade. Trata-se de uma abordagem inovadora que pretende investigar e testar as possibilidades e os limites da ideia de modernismo como movimento cultural. Seguindo a perspectiva analítica do pensamento político e social brasileiro, Marco Antonio Perruso discute numa perspectiva sociológica as classificações do pensamento brasileiro e formula uma hipótese de classificação a partir de uma referência aos principais lugares sociais de ancoragem da produção intelectual nacional, como o mercado, o Estado-Nação, a universidade e as classes e movimentos sociais de extração popular.

No oitavo artigo, "Insurgência periférica e a teoria crítica das relações internacionais”, Jaime Cesar Coelho e Laura Mabel Lacaze propõem um diálogo entre as obras de García Linera, pensador marxista e político boliviano, e Robert W. Cox, um dos fundadores da teoria crítica de relações internacionais, acenando para uma perspectiva de contestação periférica da ordem internacional. Por fim, este número se encerra com um artigo de Elizabeth del Socorro Ruano-Ibarra e Alexander Arciniegas Carreño sobre as políticas de erradicação voluntária de cultivos ilegais na Colômbia, no qual argumentam que a hegemonia do poder estadunidense, tal qual se apresenta na Colômbia, impacta a América Latina como um todo pois a agenda de drogas, segurança e controle de fronteiras é constitutiva da geopolítica estadunidense. Todos os nove artigos foram enviados 
por seus autores ao sistema de submissão do SciELO e receberam uma avaliação positiva dos nossos pareceristas, aos quais muito agradecemos.

\section{Bibliografia}

D'ERAMO, Marco. 2020. The philosopher's epidemic. New Left Review, n. 122, pp. 23-28.

FORSYTH, James. 2020. Covid is killing faith in western democracy.

The Times, 30 out. 2020.

FOUCAULT, Michel. 1975. Surveiller et punir. Paris: Gallimard.

THE PANDEMIC has eroded democracy and respect for human rights.

2020. The Economist, 17 out. 2020, pp. 50-52.

\section{Bruno Konder Comparato}

Professor do Departamento de Ciências Sociais da Universidade Federal de São Paulo (Unifesp). Guarulhos, SP, Brasil.E-mail: bruno.comparato@unifesp.br

Orcid: 0000-0001-9356-0362

http://dx.doi.org/10.1590/0102-007011/111 